\title{
Differential Expression of Mouse Neural Cell-Adhesion Molecule (N-CAM) mRNA Species During Brain Development and in Neural Cell Lines
}

\author{
Gianfranco Gennarini, ${ }^{\star}, 1$ Marie-Rose Hirsch, ${ }^{*}$ Hai-Tao He, ${ }^{*}$ Michel Hirn, ${ }^{*}$ Jukka Finne, $\dagger$ and \\ Christo Goridis* \\ ${ }^{*}$ Centre d'Immunologie INSERM-CNRS de Marseille-Luminy, Marseille, France, and †Department of Biochemistry, \\ Biocenter of the University of Basel, Basel, Switzerland
}

The cell-adhesion molecules N-CAM (neural cell-adhesion molecule) are ligands in the formation of cell-cell bonds and have been shown to play important roles during neuro-ontogenesis. They exist in several molecular forms which differ at the protein and carbohydrate levels. The regulation of the expression of these different forms is an important issue that bears on such questions as to how adhesive interactions between cells are modulated during morphogenesis. In the present study we have used N-C.AM cDNA clones to investigate the expression of the cognate mRNAs in the mouse and rat brain and in 2 neural cell lines. The results were compared with the levels of the different N-CAM proteins. We made the following observations. (1) A complex set of 5 size classes of mRNAs-which show developmental, regional, and cell-type-dependent variations in their expression-hybridize to 1 of our cDNA probes. While embryonic brain contains $\mathrm{N}-\mathrm{CAM}$ gene transcripts $7.4,6.7$, and 4.3 kilobases (kb) in length, 2 additional mRNAs of 5.2 and $2.9 \mathrm{~kb}$ appear postnatally. Transformed brain cells of an astrocytic character express predominantly mRNAs of $6.7,4.3$, and 2.9 $\mathrm{kb}$ and a neuroblastoma line those of $7.4,6.7,4.3$, and $2.9 \mathrm{~kb}$. (2) There are important quantitative changes in the amount of $\mathrm{N}$-CAM message expressed during brain development, with a peak around birth, suggesting that N-CAM synthesis is controlled at the transcriptional level. (3) A comparison of N-CAM protein and mRNA levels reveals a striking correlation between the relative concentrations of the $M_{\mathrm{r}} 120,000 \mathrm{~N}-\mathrm{CAM}$ protein $\left(\mathrm{N}-\mathrm{CAM}_{120}\right)$ and the $5.2 \mathrm{~kb}$ transcript. (4) The 5.2 and $2.9 \mathrm{~kb}$ mRNA species lack $3^{\prime}$ gene sequences. These results support the view that the $5.2 \mathrm{~kb}$ mRNA codes for $\mathrm{N}-\mathrm{CAM}_{120}$, since in this protein the $\mathrm{C}$-terminal extensions found in the 2 other N-CAM proteins are absent.

The cell-surface glycoproteins called N-CAM (neural cell-adhesion molecule) are to date the best known cell-cell adhesion molecules of the vertebrate nervous system. They have been purified, characterized chemically, and shown to be ligands in the formation of cell-cell bonds (for reviews, see Edelman et al., 1983; Goridis et al., 1983a; Rutishauser, 1983). Recent in vivo results confirm the significance of $\mathrm{N}$-CAM-mediated cell adhesion in nervous system development (Fraser et al., 1984;

Received Sept. 6, 1985; revised Nov. 6, 1985; accepted Nov. 14, 1985

We wish to thank M. Mallat and A. Prochiantz for the kind gift of the F7 cell line. This work was supported by a grant from the CNRS. G.G. was the holder of a fellowship from the Fondation Simone et Cino del Duca.

Correspondence should be addressed to C. Goridis, Centre d'Immunologie INSERM-CNRS de Marseille-Luminy, Case 906, 13288 Marseille Cedex 9, France.

On leave from the Istituto di Fisiologia Umana, Facolta di Medicina e Chirurgia, Universita degli Studi di Bari, Policlinico, Piazza G. Cesare, I-70124 Bari, Italy.

Copyright (C) 1986 Society for Neuroscience $0270-6474 / 86 / 071983-08 \$ 02.00 / 0$
Thanos et al., 1984). In the rodent nervous system, N-CAM has been found on most central and peripheral neurons, on astrocytes, and on some peripheral glial cells (Chuong et al., 1982; Faissner et al., 1984; Goridis et al., 1983b; Langley et al., 1982, 1983; Lyles et al., 1984; Noble et al., 1985).

Variations in the expression of cell-adhesion molecules from one cell type or developmental stage to another can be presumed to be of fundamental importance to neuro-ontogenesis. Indeed, different forms of N-CAM whose expression depends on cell type or developmental stage have been identified. Three size classes of N-CAM proteins with apparent molecular weights of $180,000,140,000$ and 120,000 (hereafter N-CAM 180, N-CAM $_{140}$, and $\mathrm{N}-\mathrm{CAM}_{120}$ ) are present in the adult mouse and rat brain (Chuong et al., 1982; Ibsen et al., 1983; Rougon et al., 1982) and show regional and cell-type-specific modulations in their expression (Chuong and Edelman, 1984; Keilhauer et al., 1985; Noble et al., 1985; Rougon et al., 1982). The size differences between $\mathrm{N}-\mathrm{CAM}_{180}, \mathrm{~N}-\mathrm{CAM}{ }_{140}$, and $\mathrm{N}-\mathrm{CAM}_{120}$ are primarily due to differences in the lengths of their C-terminal domains (Cunningham et al., 1983; Gennarini et al., 1984a). During development, the so-called "embryonic" form of N-CAM from immature nervous tissuc, which is highly sialylated, is gradually converted into a less sialylated "adult" form (Chuong et al., 1982; Hirn et al., 1983; Rougon et al., 1982). Most of the sialic acid in both the embryonic and adult molecules is present as unusual sialic acid polymers (Finne et al., 1983). Because of its long polysialic acid side chains, embryonic N-CAM migrates atypically in SDS-PAGE as a broad zone in the 170,000-250,000 $M_{\mathrm{r}}$ region. This unusual migration pattern has made it difficult to reveal the underlying polypeptide chains (Hirn et al., 1983). Since very similar, if not identical, peptide fragments can be generated from embryonic and adult N-CAM, their polypeptide chains have been assumed to be identical (Chuong et al., 1982; Gennarini et al., 1984a; Rougon et al., 1982).

At present, it is not known exactly how the 3 polypeptide components of mouse and rat N-CAM are generated, but in vitro data suggest that they are translated from different mRNAs (Hansen et al., 1985). Nor is anything known about the mechanism regulating $\mathrm{N}$-CAM levels during brain development (Chuong and Edelman, 1984). Recently, cDNA clones for chicken (Murray et al., 1984) and mouse (Goridis et al., 1985) N-CAM have been isolated. These probes now make it possible to investigate qualitative and quantitative changes in the expression of N-CAM at the mRNA or gene level. In the present study, 2 mouse N-CAM cDNA probes were used to identify the cognate mRNAs in mouse and rat brain and in 2 mouse neural cell lines. Five distinct mRNA size classes of high $M_{\mathrm{r}}$ that exhibit developmental-stage and cell-type specificity in their expression were detected by these probes. A comparison of polypeptide and mRNA expressions revealed a striking correlation between the 


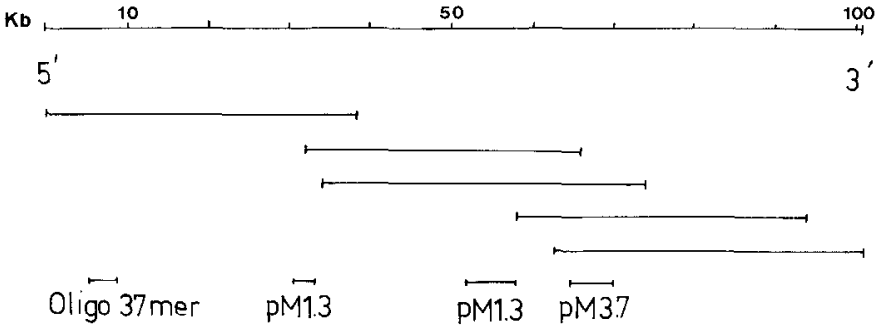

Figure 1. Overview of mouse genomic cosmid clones containing the $\mathrm{N}$-CAM gene showing the regions of homology with an oligonucleotide probe derived from the N-terminal N-CAM sequence and with the 2 clones pM1.3 and pM3.7. Five overlapping cosmid clones were isolated from a Balb/c mouse genomic library (Goridis and Steinmetz, unpublished results). An oligonucleotide of 37 bases corresponding to the N-terminal protein sequence of N-CAM was kindly provided by $M$. Brownstein and $G$. Rougon. The length of the genomic sequences is given in kilobases. The approximate location of the regions to which the oligonucleotide (Oligo $37 \mathrm{mer}$ ) and the cDNA probes pM1.3 and pM3.7 hybridize is shown.

abundance of one mRNA species and the prevalence of $\mathrm{N}-\mathrm{CAM}_{120}$. Furthermore, we show that the down-regulation of N-CAM abundance during development is controlled at the transcriptional level or by mRNA stabilization.

\section{Materials and Methods}

\section{Cells and antibodies}

The F7 cell line was derived by M. Mallat and A. Prochiantz from a primary culture of embryonic day 14 mouse mesencephalon by transformation with SV40 virus (Mura Neto et al., 1986). The cells were cultured in Dulbecco's modified Eagle's medium with $10 \%$ fetal calf serum. The C1300-derived mouse neuroblastoma line Neuro $2 \mathrm{a}(\mathrm{N} 2 \mathrm{a})$ was cultured in the same medium. The preparations and specificities of the rat anti-mouse N-CAM monoclonal antibodics (mAb) H28 and P61 (Gennarini et al., 1984b; Hirn et al., 1981) and of the rabbit antiN-CAM serum (Gennarini et al., 1984b; Sadoul et al., 1983) have been described.

\section{cDNA probes}

The isolation and preliminary characterization of cDNA clones coding for N-CAM have been described (Goridis et al., 1985). Two clones, pM1.3 and pM3.7, were used in the present study. Their translation products are recognized by monoclonal antibodies H28 and P61 (Gennarini et al., 1984b), respectively. Both clones thus contain coding sequences corresponding to different regions of the gene. Evidence that the 2 cDNAs code for N-CAM includes the recognition of their translation products by mono- and polyclonal anti-N-CAM antibodies, and the presence of overlapping sequences in clones identified with 2 different monoclonal antibodies (Goridis et al., 1985). Moreover, recent results (to be published elsewhere), show that both cDNAs hybridize to adjacent regions of the same genomic cosmid clone and that an overlapping cosmid hybridizes to an oligonucleotide probe derived from the N-terminal amino acid sequence of mouse $\mathrm{N}-\mathrm{CAM}_{180}$ and N-CAM ${ }_{140}$ (Goridis and Steinmetz, unpublished observations). In Figure 1, an overview is given of the genomic clones containing the N-CAM gene with the respective locations of the regions to which the oligonucleotide probe and the 2 cDNAs hybridize. These data confirm that $\mathrm{pM} 1.3$ contains sequences located $5^{\prime}$ to those contained in pM3.7. This arrangement had previously been deduced from the location on the protein of the $\mathrm{H} 28$ and $\mathrm{P} 61$ epitopes, since the $\mathrm{H} 28$ determinant borne by the pM1.3 product has been mapped at the $\mathrm{N}$-terminal side of the sequence recognized by P6 1 , the $\mathrm{mAb}$ used for identification of pM3.7 (Gennarini et al., 1984a; Goridis et al., 1985). In Northern blots, pM1.3 detects only high $M_{\mathrm{r}}$ mRNA bands exclusively present in N-CAM-expressing tissues and cells. In addition to these bands, pM3.7 detects 2 RNAs of smaller size that are expressed in similar amounts in all mouse tissues tested (Goridis et al., 1985, and unpublished observations).

The inserts of the 2 plasmids were liberated by EcoRI digestion, purified by agarose gel electrophoresis, and recovered by electroelution.
They were labeled to high specific activity $\left(8-30 \times 10^{8} \mathrm{cpm} / \mu \mathrm{g}\right.$ DNA) by the method of Feinberg and Vogelstein (1984).

\section{Gel blot analysis of $m R N A$}

Total cellular RNA was extracted from brain and liver of Swiss mice or rats of the Lou/WSI strain by the guanidinium-cesium chloride method (Maniatis et al., 1982) and cytoplasmic RNA from N2a and F7 cells according to Favaloro et al. (1980). The results were the same when the guanidinium-cesium chloride method was applied to frozen pellets of cultured cells. Poly $(\mathrm{A})^{+}$RNA was purified either by the messenger affinity paper (Medac, Hamburg, FRG) method (Werner et al., 1984) or by one cycle of chromatography on oligo (dT)-cellulose (Maniatis et al., 1982) with identical results.

Samples of poly(A) ${ }^{+}$RNA were electrophoresed on $0.8 \%$ agarose in the presence of formaldehyde (Lehrach et al., 1977) and transferred to nitrocellulose (Thomas, 1980). The filters were prehybridized at $42^{\circ} \mathrm{C}$ for $6-8 \mathrm{hr}$ in $50 \%$ formamide, $5 \times \operatorname{SSC}(1 \times$ SSC is $0.15 \mathrm{M} \mathrm{NaCl} / 0.015$ M sodium citrate) $50 \mathrm{~mm}$ sodium phosphate buffer (pH 6.8), $0.1 \%$ SDS, $5 \times$ Denhardt solution (Maniatis et al., 1982) containing $200 \mu \mathrm{g} / \mathrm{ml}$ sheared, denatured salmon sperm DNA. Hybridization itself was done at $42^{\circ} \mathrm{C}$ for $40 \mathrm{hr}$ in the same solution with $3 \times 10^{6} \mathrm{cpm} / \mathrm{ml}$ of labeled probe. The filters were then briefly rinsed in $2 \times \mathrm{SSC}, 0.1 \%$ SDS at $65^{\circ} \mathrm{C}$, washed first 3 times for $20 \mathrm{~min}$ at $65^{\circ} \mathrm{C}$ in $2 \times$ SSC, $0.1 \%$ SDS, then 3 times at $65^{\circ} \mathrm{C}$ for $20 \mathrm{~min}$ in $0.2 \times$ SSC, $0.1 \%$ SDS. After a final rinse in $2 \times \mathrm{SSC}$ at room temperature, the filters were exposed to Fuji RX films at $-70^{\circ} \mathrm{C}$ in the presence of sensitizing screens for $1-4 \mathrm{~d}$. Since probes of different specific activities were used, the signal intensities obtained on different blots are not strictly comparable. Densitometric scanning of autoradiographs, in the linear range of film responses, was done with a LKB 2202 ultroscanner.

\section{Gel blot analysis of proteins}

Nonidet-P40 extracts of tissue samples were prepared, fractionated by 6.7\% SDS-PAGE and transferred to nitrocellulose as described (Hirn et al., 1983). Frozen pellets of F7 or N2a cells were directly dissolved in electrophoresis buffer. The filters were saturated with $3 \%$ bovine hemoglobin in phosphate-buffered saline (Hb/PBS) for $1 \mathrm{hr}$ at $37^{\circ} \mathrm{C}$. Incubation with $\mathrm{H} 28 \mathrm{mAb}$ in the form of hydridoma supernatant diluted $1: 5$ in $\mathrm{Hb} / \mathrm{PBS}$ or with rabbit anti-N-CAM serum diluted $1: 1000$ in $\mathrm{Hb} /$ PBS was for $14 \mathrm{hr}$ at $4^{\circ} \mathrm{C}$. The filters were washed several times in PBS, resaturated with $\mathrm{Hb} / \mathrm{PBS}$, and incubated for $1 \mathrm{hr}$ at room temperature with ${ }^{125} \mathrm{I}$-labeled rabbit anti-(rat $\mathrm{Ig}$ ) or goat anti-(rabbit Ig) antibodies in $\mathrm{Hb} / \mathrm{PBS}$. After more washes in PBS, the filters were exposed to Fuji RX films at $-70^{\circ} \mathrm{C}$ in the presence of sensitizing screens for $1-2 \mathrm{~d}$.

An endosialidase associated with the bacteriophage PK1A specific for $E$. coli of the capsular type $\mathrm{K} 1$ was purified as described (Finne and Mäkelä, 1985). This enzyme cleaves polymers of $\alpha 2-8$-linked $N$-acetylneuraminic acid with a minimum chain length of 8 residues, leaving 5 residues attached to the proximal (reducing end) side. Nonionic detergent extracts of tissue samples were incubated with $0.4 \mathrm{U}$ of enzyme for $4 \mathrm{hr}$ at $37^{\circ} \mathrm{C}$ in the presence of the following protease inhibitors: 5 $\mathrm{mm}$ iodoacetamide, $10 \mathrm{U} / \mathrm{ml}$ aprotinin, $1 \mathrm{~mm}$ phenylmethyl sulfonylfluoride, $0.1 \mathrm{~mm}$ pepstatin, and $0.1 \mathrm{~mm}$ leupeptin. One unit of endosialidase activity is defined as the amount needed to cleave $50 \mu \mathrm{g} \mathrm{col}-$ ominic acid in $24 \mathrm{hr}$ at $37^{\circ} \mathrm{C}$.

\section{Results}

\section{Complex pattern of $N$-CAM-related $m R N A s$ is revealed in} mouse brain

Northern blot analysis of poly(A)+ RNA from mouse brain with the N-CAM CDNA probe pM1.3 yielded a complex pattern of common hybridization bands. Five distinct size classes of mRNA were detected in postnatal-day 10 mouse forebrain (Fig. 2, lanes marked 2). By comparison with the migration of DNA restriction fragments, their sizes were estimated to be $7.4,6.7,5.2$, 4.3 , and $2.9 \mathrm{~kb}$. These estimates correspond to the means recorded using different gels and different sets of markers. On very long gels, the 2.9 and $4.3 \mathrm{~kb}$ bands migrated as closcly spaced doublets (see Fig. $3 B$, lane $5^{\prime}$, and Fig. $6 B$ ). Only the transcripts of $7.4,6.7$, and $4.3 \mathrm{~kb}$ hybridized to probe pM3.7 as well. The hybridization signal intensity was different for each band, indicating either that variable amounts of different length $\mathrm{mRNAs}$ 
are synthesized from the same gene or that different but related genes are transcribed to yield multiple-sized transcripts. As reported previously (Goridis et al., 1985) and as shown here for mouse liver (Fig. 2, lanes marked 1), none of the bands detected by pM1.3 was present in N-CAM negative tissues. By contrast, clone pM3.7 recognized 2 additional mRNAs of smaller size $(\sim 1.0$ and $\sim 2.0 \mathrm{~kb})$ found in all mouse tissues analyzed. The same band pattern was obtained when total RNA $(20 \mu \mathrm{g})$ was analyzed, but the intensities of the bands were much weaker (results not shown) indicating that all species detected bear poly $(\mathrm{A})^{+}$tails.

\section{Developmental stage-specific expression of $N-C A M m R N A$ species and corresponding changes in $\mathrm{N}$-CAM proteins}

Striking changes in the level of expression of N-CAM mRNAs were found when poly $\left(\mathrm{A}^{+}\right)$RNA from mouse forebrain of different ages was analyzed (Fig. $3 B$ ). The highest levels of mRNAs hybridizing with the pM1.3 insert were expressed at postnatal day 2 , somewhat less at embryonic day 17 , and considerably less in the adult. Some 2.5 times more RNA from P40 mouse forebrain was loaded on the gel shown in lane $5^{\prime}$ and the autoradiograph exposed 3 times longer to make the bands visible. Densitometric measurements of the total hybridizing material in lanes 2 and 5 revealed a 5.8 -fold decrease between postnatal days 2 and 40 . When the $2.9 \mathrm{~kb}$ band, which is probably too small to code for any of the known N-CAM polypeptides, was excluded from the analysis, the drop was even greater, i.e., 9.5fold. We confirmed that identical amounts of poly $\left(\mathrm{A}^{+}\right)$RNA had been applied to each lane in Figure $3 B$ by hybridizing the same blot with a $0.5 \mathrm{~kb}$ BgIII/EcoRI fragment of the pM2.2 insert (Goridis et al., 1985), which detects a $\sim 1 \mathrm{~kb}$ message present in equivalent amounts in all mouse tissues and at all developmental stages (unpublished observations). As seen in Figure $3 B$, lower panel, signals of equal intensity were obtained for the 5 developmental stages.

Not only the absolute amounts of N-CAM mRNA transcribed in the brain, but also the prevalance of the individual bands and the ratios between them changed during development. At the same level of exposure, the 5.2 and $2.9 \mathrm{~kb}$ mRNAs could not be detected in poly $\left(\mathrm{A}^{+}\right)$RNA from embryonic day 17 forebrain (Fig. $3 B$, lane 1). They were faintly visible at postnatal day 2 (lane 2) and became relatively stronger during further development. By contrast, the band of $4.3 \mathrm{~kb}$, as well as the 7.4 and $6.7 \mathrm{~kb}$ bands, decreased in intensity as development proceeded. In the adult pattern (lanes 5 and $5^{\prime}$ ), the transcripts of 2.9 and $5.2 \mathrm{~kb}$ were present in the relatively highest amounts, the 6.7 and $7.4 \mathrm{~kb}$ bands were weaker, and the $4.3 \mathrm{~kb}$ species was absent. Changes in the proportions of the 2 highest $M_{\mathrm{r}}$ species were also recorded. They were present in almost equimolar amounts at birth, but the $6.7 \mathrm{~kb}$ band was more intense from postnatal day 15 on.

The observed developmental changes in the levels of the mRNAs were confronted with an immune blot analysis of N-CAM polypeptides present in the same material (Fig. 3A). To reveal the underlying polypeptides in the diffusely migrating embryonic form, present up to postnatal day 15 in mouse forebrain, we used the enzyme endosialidase which rapidly and quantitatively cleaves the long sialic acid polymers of embryonic N-CAM (Finne and Mäkelä, 1985). This treatment revealed the presence of 2 major immunoreactive bands of $M_{\mathrm{r}} 180,000$ and 140,000 in the embryonic brain (Fig. $3 A$, lane $1^{+}$). An $M_{r} 120,000$ species was not detected. Since the latter polypeptide exists in part in a nonionic-detergent-insoluble form (unpublished observations), the Nonidet-P40 pellet was analyzed as well (lanes $1 \mathrm{c}-5 \mathrm{c})$. Once again, no trace of a $M_{\mathrm{r}} 120,000$ band was visible at embryonic day 17 . A N-CAM ${ }_{120}$ polypeptide was first detectable at postnatal day 2 in the insoluble material, became gradually stronger at later stages, and was then also present in

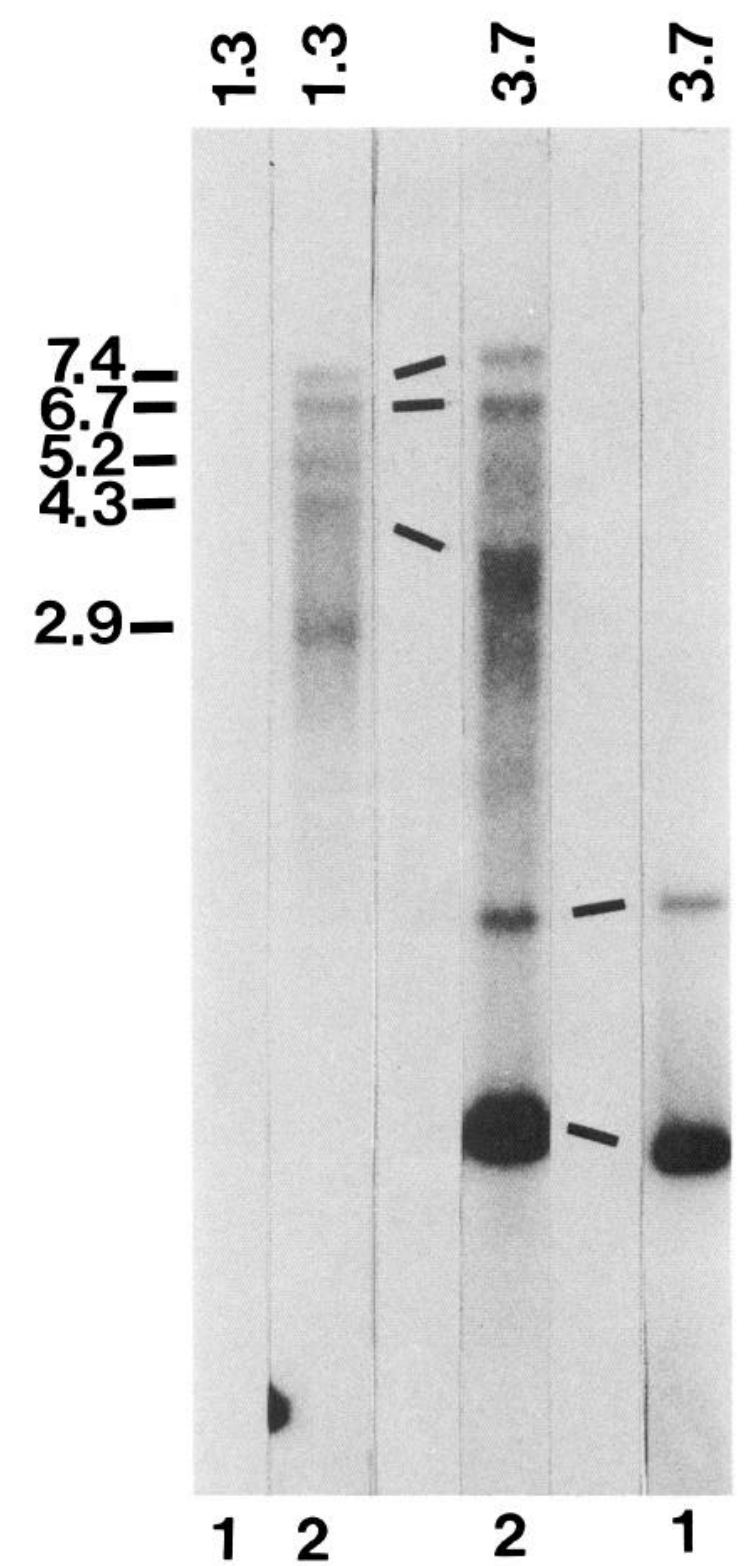

Figure 2. Expression of different size classes of N-CAM mRNA in young postnatal mouse brain. Total poly(A) ${ }^{+}$RNA isolated from postnatal day 10 forebrains (lanes 2 ) or livers (lanes 1 ) was fractionated by electrophoresis on formaldehyde-containing $0.8 \%$ agarose gels, transferred to nitrocellulose, and hybridized with the gel-purified ${ }^{32} \mathrm{P}$-labeled inserts of either clone pM1.3 (1.3) or pM3.7 (3.7). The sizes of RNA bands, estimated from the position of denaturated phage DNA restriction fragments of known lengths run in parallel on the same gel, are indicated in kilobase (kb) at left. Note the absence of bands at 5.2 and $2.9 \mathrm{~kb}$ in the forebrain sample hybridized with probe pM3.7.

the Nonidet-P40 extract. Hence, the developmental appearance of this component followed a similar time course as the expression of the 5.2 and $2.9 \mathrm{~kb}$ mRNAs. By contrast, the ratios between N-CAM ${ }_{180}$ and N-CAM ${ }_{140}$ changed very little, if at all, during development.

\section{Expression of $N$-CAM proteins and $m R N A$ s in young postnatal rat brain}

An analysis of N-CAM gene transcripts and proteins in postnatal day 10 rat forebrain yielded very similar results as observed in mice of an equivalent developmental stage. Since the $\mathrm{H} 28 \mathrm{mAb}$ does not cross-react with rat N-CAM, a rabbit anti-N-CAM 


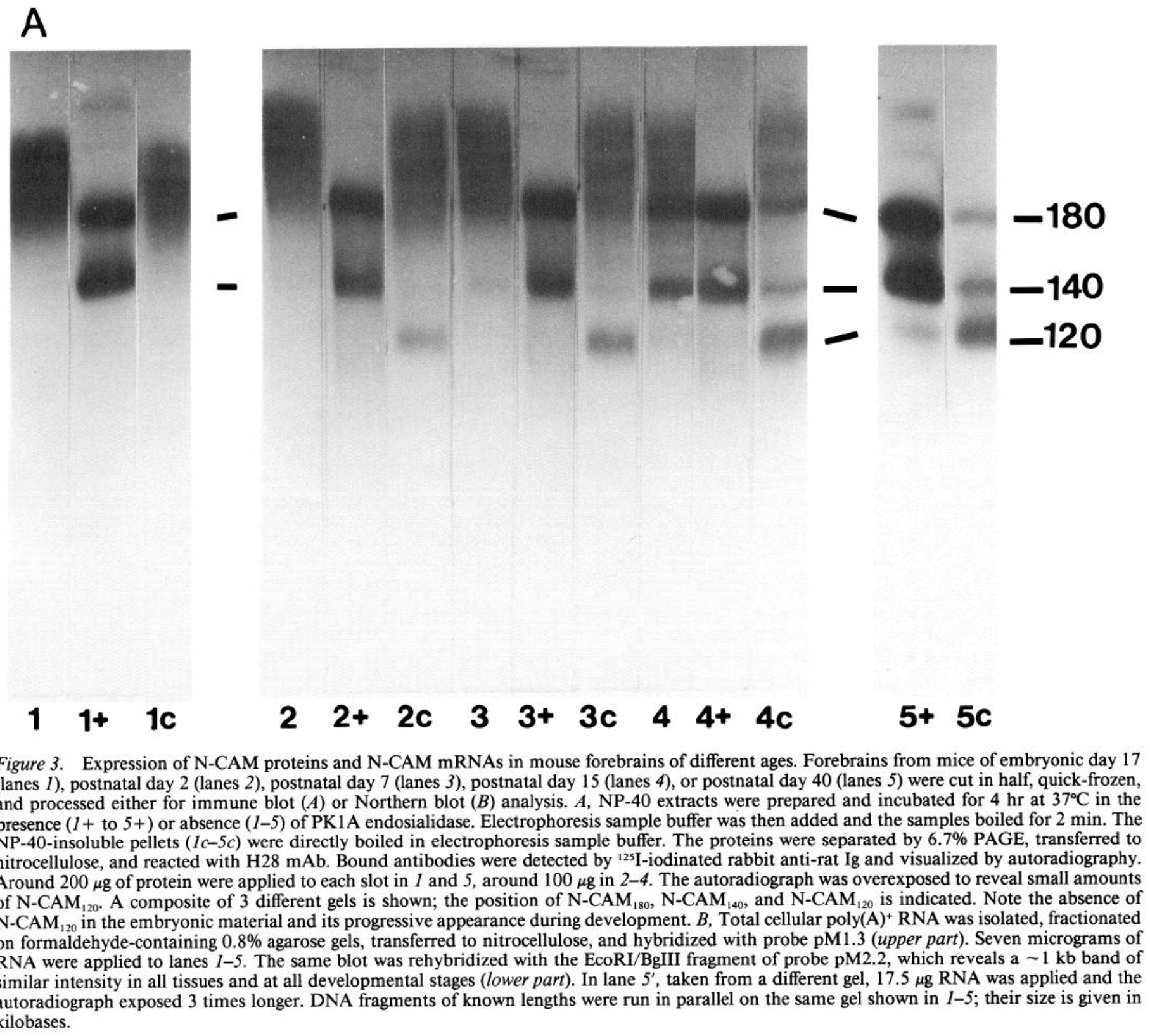

serum was used for immune blot analysis (Fig. $4 A$ ). There were still considerable amounts of the polysialylated embryonic form. After endosialidase treatment, strong N-CAM ${ }_{180}$ and N-CAM 140 bands were revealed in detergent extracts. Small amounts of $\mathrm{N}-\mathrm{CAM}_{120}$ were present before and after treatment. In Northern blots, probe pM1.3 hybridized to discrete 7.4, 6.7, 5.2, 4.3, and $2.9 \mathrm{~kb}$ bands (Fig. $4 B$ ). A faint $3.5 \mathrm{~kb}$ species was also present. As in young postnatal mouse brain, the 2 highest $M_{\mathrm{r}}$ classes were predominant and the $5.2 \mathrm{~kb}$ band rather weak. Again, the 5.2 and $2.9 \mathrm{~kb}$ transcripts were not detected by pM3.7. Interestingly, pM3.7 did not hybridize to the $\sim 1$ and $\sim 2 \mathrm{~kb}$ RNAs in the rat.

\section{Correlation between $N-C A M m R N A$ and polypeptide expression in 2 brain regions and neural cell lines}

The relative amounts of the $3 \mathrm{~N}-\mathrm{CAM}$ polypeptides have been found to differ from one region of the adult mouse brain to another (Chuong and Edelman, 1984; Rougon et al., 1982). To correlate the results obtained on the protein level with Northern blot analysis of the cognate messages, we examined 2 regions of the adult mouse brain, the olfactory bulb and the optic tectum. These structures were chosen because they can be dissected out easily, thus minimizing the risk of RNA degradation. Immune blots with $\mathrm{H} 28 \mathrm{mAb}$ showed the typical 3 band pattern in both regions (Fig. $5 \mathrm{~A}$ ). $\mathrm{N}-\mathrm{CAM}_{180}$ and $\mathrm{N}-\mathrm{CAM}_{140}$ were present in approximately equal amounts in the tectum, but there was more N-CAM ${ }_{180}$ in the bulb. In the olfactory bulb, the 2 higher $M_{\mathrm{r}}$ bands were considerably more intense than the 120,000 component, which was not the case in the tectum. It has been reported (Chuong and Edelman, 1984) that in both structures, the embryonic form persists in the adult, but in our hands, endosialidase digestion produced little, if any, change in the migration patterns (not shown).

In Northern blots, probe pM1.3 hybridized to the same size classes of gene transcripts that had been observed in adult mouse forebrain (Fig. $5 B$ ). However, differences in the relative abundance of the bands were noted in olfactory bulb and tectum. In the tectum, the proportion of the 5.2 and $2.9 \mathrm{~kb}$ species was higher. (In this respect, optic tectum resembled adult mouse forebrain more than the olfactory bulb.) The $7.4 \mathrm{~kb}$ band was 


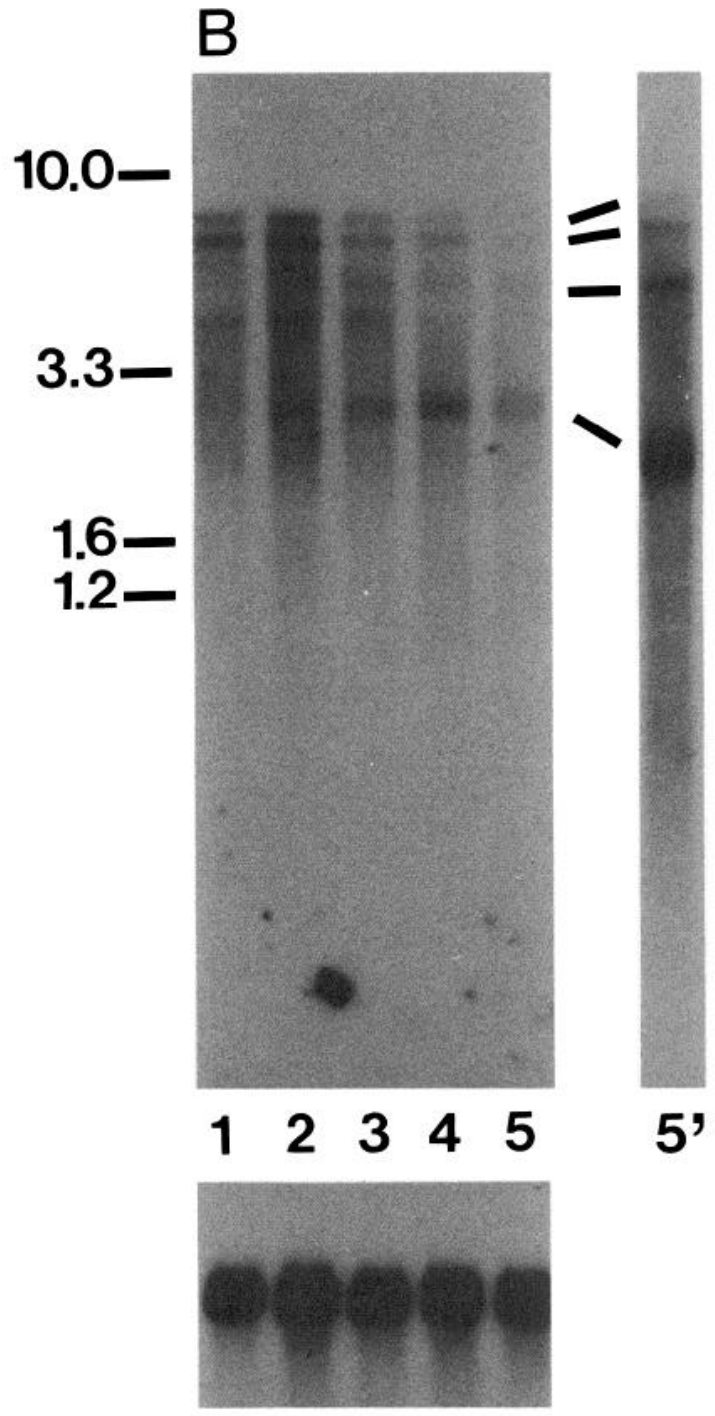

Figure 3. (Continued)

more intense than the $6.7 \mathrm{~kb}$ component in the tectum, whereas the opposite was found in the olfactory bulb. There was thus a correlation between the prevalence of $\mathrm{N}-\mathrm{CAM}_{120}$ and of the 5.2 and $2.9 \mathrm{~kb}$ mRNAs in the 2 brain regions, but not between the relative abundance of $\mathrm{N}-\mathrm{CAM}_{180}$ and $\mathrm{N}-\mathrm{CAM}_{140}$ and the 7.4 and $6.7 \mathrm{~kb}$ messages.

Two cell lines of nervous system origin were subjected to the same kind of analysis. The neuroblastoma C1300-derived line $\mathrm{N} 2 \mathrm{a}$, which expresses functional N-CAM molecules (Sadoul et al., 1983), may be taken as the equivalent of an immature peripheral neuron; the SV40-transformed cell line F7 has been shown to express astrocytic markers (Mura Neto et al., 1985). In F7 cells, $\mathrm{N}-\mathrm{CAM}_{140}$ was found to predominate (Fig. $6 \mathrm{~A}$ ). Only traces of a 180,000 component were detected and N-CAM 120 was totally absent. The low expression of the N-CAM ${ }_{180}$ by these cells may be related to their astrocytic character, since cultured astrocytes have been reported to be deficient in this chain (Noble et al., 1985). An equally simple pattern was also observed for these cells in Northern blots, probed with pM1.3. It consisted of an intense $6.7 \mathrm{~kb}$ band and a 4.3 and a $2.9 \mathrm{~kb}$ species. At the

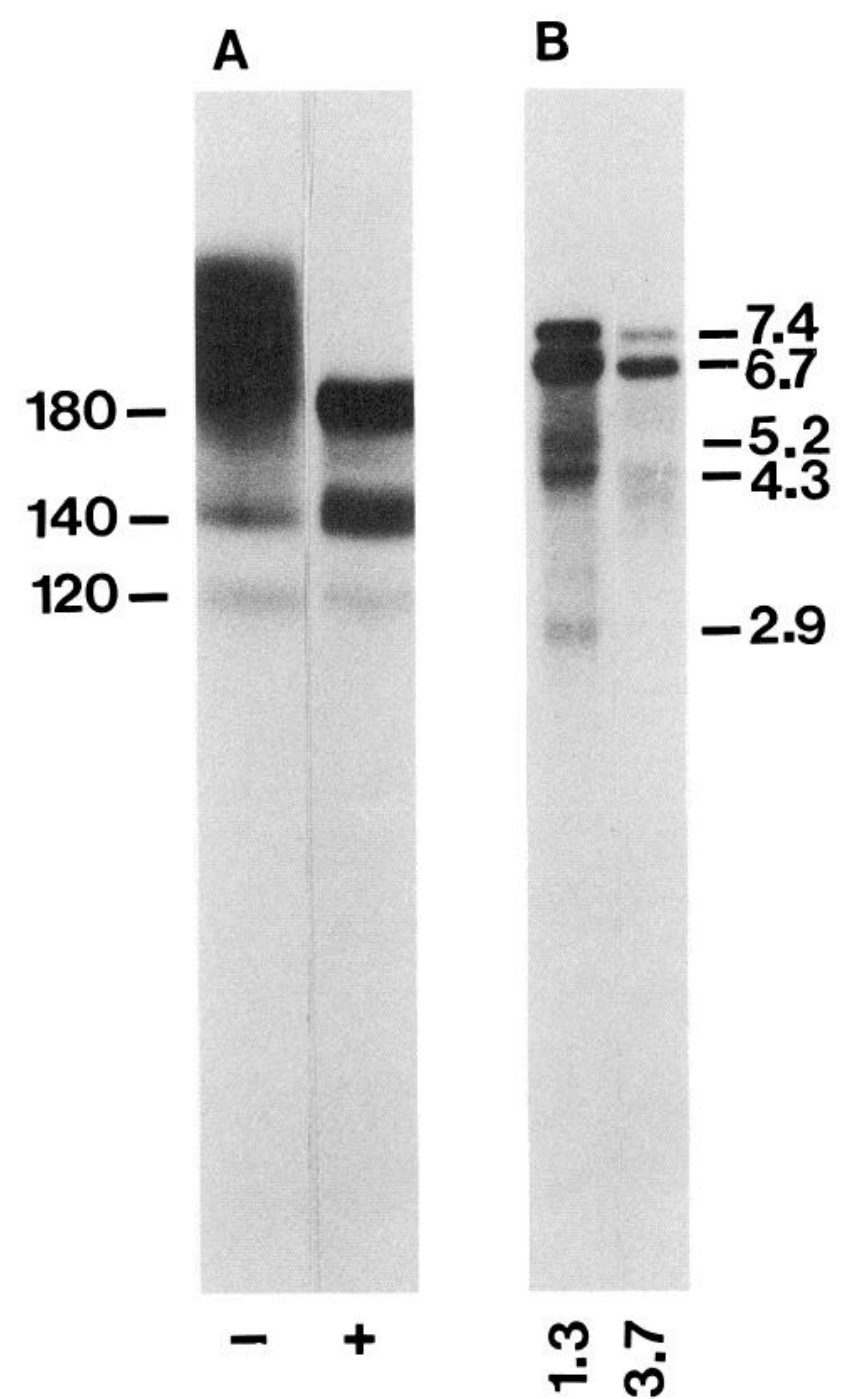

Figure 4. N-CAM proteins $(A)$ and mRNAs $(B)$ expressed in postnatal day 10 rat forebrain. $A, \mathrm{NP}-40$ extracts were incubated for $4 \mathrm{hr}$ at $37^{\circ} \mathrm{C}$ in the absence $(-)$ or presence $(+)$ of PK1A endosialidase and N-CAM polypeptides revealed with rabbit anti-N-CAM serum and ${ }^{125}$ I-iodinated protein A. B, Northern blots similar to those in Figure 1 were performed with $10 \mu \mathrm{g}$ total poly(A) ${ }^{+}$RNA. The blots were hybridized with either probe pM1.3 (lane 1.3) or pM3.7 (lane 3.7). The positions of N-CAM $\mathrm{N}-\mathrm{CAM}_{140}$, and N-CAM 120 and the size of the mRNA bands are indicated.

same level of exposure, a $7.4 \mathrm{~kb}$ component was not detectable (Fig. 6B).

Immune blots of $\mathrm{N} 2 \mathrm{a}$ cells showed the presence of N-CAM 140 and of somewhat lower amounts of $\mathrm{N}-\mathrm{CAM}_{180}$ (Fig. 6A). A faint band at the position of N-CAM ${ }_{120}$ became visible after overexposure of the autoradiographs (not shown). Northern blots of the same cells probed with pM1.3 revealed strong mRNA bands at $6.7,4.3$, and $2.9 \mathrm{~kb}$ and a weaker band at $7.4 \mathrm{~kb}$ (Fig. $6 B$ ). Between the 6.7 and $4.3 \mathrm{~kb}$ bands, 2 faint bands were also present, of which the smaller comigrated with the $5.2 \mathrm{~kb}$ mRNA from adult brain.

During brain development and in the 2 adult brain regions, concomitant changes in the amount of the 2.9 and $5.2 \mathrm{~kb}$ species were observed. This was clearly not the case for F7 and N2a cells, in which the $2.9 \mathrm{~kb}$ band was readily detectable, whereas the $5.2 \mathrm{~kb}$ mRNA was very weakly expressed or absent. 


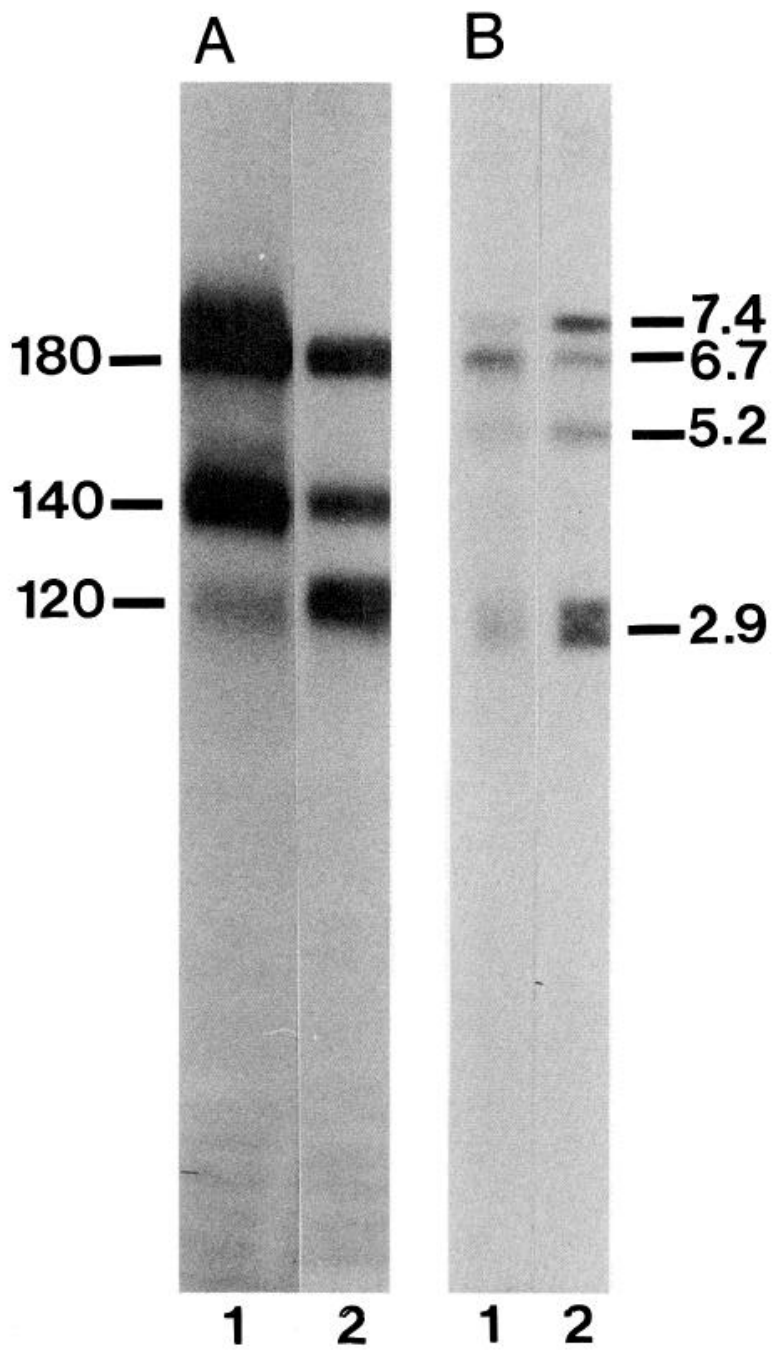

Figure 5. Comparison of N-CAM proteins $(A)$ and mRNAs $(B)$ expressed in adult mouse olfactory bulb (lanes $I$ ) or optic tectum (lanes 2). $A$, NP-40 extracts were resolved by $6.7 \%$ PAGE, transferred to nitrocellulose, and reacted with $\mathrm{H} 28 \mathrm{mAb}$ and ${ }^{125}$ I-iodinated rabbit antirat Ig. Position of N-CAM ${ }_{180}, \mathrm{~N}-\mathrm{CAM}_{140}$, and N-CAM ${ }_{120}$ as indicated. $B$, Northern blot analysis of the same material was performed with 10 $\mu \mathrm{g}$ total poly $(\mathrm{A})^{+}$RNA. N-CAM mRNAs were revealed with probe pM1.3, their size is given in kilobases (kb). In this particular gel, the $2.9 \mathrm{~kb}$ band was resolved into a closely spaced doublet.

\section{Discussion}

The N-CAMs are a group of cell-surface glycoproteins that mediate cell-cell adhesion, in particular between neural cells (for reviews, see Edelman et al., 1983; Goridis et al., 1983; Rutishauser, 1983). Changes in both the molecular forms and the abundance of these proteins have been observed during development and in different cell types (Chuong and Edelman, 1984; Chuong et al., 1982; Noble et al., 1985; Rougon et al., 1982), and these changes have, in part, been correlated with modulation of their adhesive properties (Hoffman and Edelman, 1983; Sadoul et al., 1983). As yet, however, very little information has been obtained on how the different forms of N-CAM are generated and how their expression is regulated. As a first step in clarifying these issues, we compared the N-CAM gene transcripts expressed in the rodent brain and in 2 neural cell lines with the levels of the different N-CAM proteins present in the same material.

Using the N-CAM and cDNA probe pM1.3, we detect 5

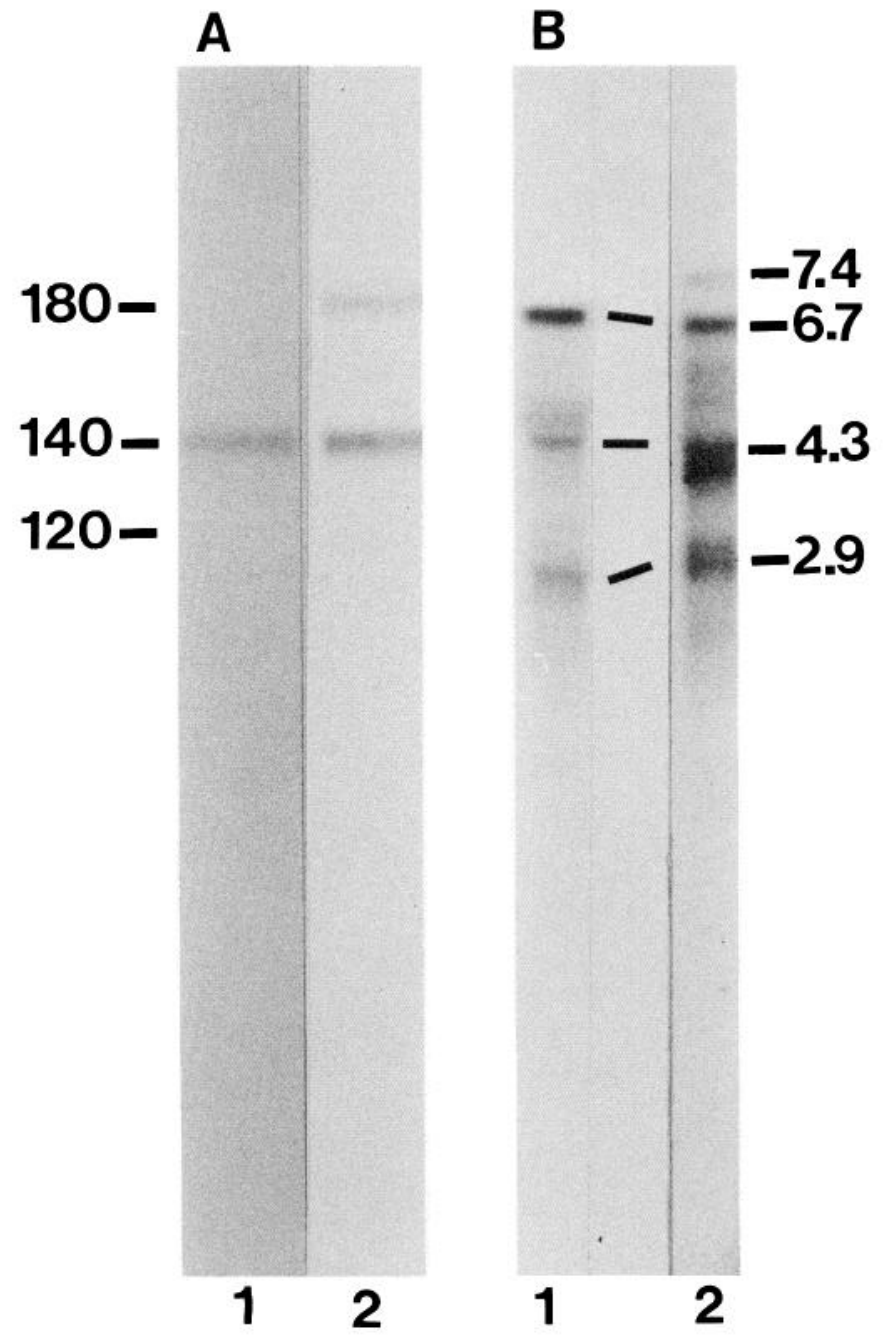

Figure 6. Comparison of N-CAM proteins $(A)$ and mRNAs $(B)$ expressed by 2 neural cell lines, the SV-40 transformed F7 line (lanes 1 ) and the neuroblastoma N2a (lanes 2). A, F7 or N2a cells were directly dissolved in electrophoresis sample buffer and analyzed for N-CAM protein expression by immune blot analysis with mAb H28. The positions of N-CAM $180, \mathrm{~N}-\mathrm{CAM}_{140}$, and N-CAM ${ }_{120}$ from a brain sample run in parallel on the gel is given at left. A faint band in N2a cells at the position of N-CAM ${ }_{120}$ becomes visible at longer exposures of the autoradiographs (not shown). B, Cytoplasmic poly(A)+ RNA was isolated from sister cultures, fractionated on $0.8 \%$ agarose gels in the presence of formaldehyde, transferred to nitrocellulose, and hybridized with probe pM1.3. RNA, $10 \mu \mathrm{g}$, was applied to both lanes. The size of the mRNA bands is given in kilobases.

different size classes $(7.4,6.7,5.2,4.3$, and $2.9 \mathrm{~kb})$ of mRNA species, the expression of which changes with developmental stage or cell type. Two transcripts (5.2 and $2.9 \mathrm{~kb})$ are not visible in the embryonic forebrain and $1(4.3 \mathrm{~kb})$ disappears in the adult. The ratio between the 7.4 and $6.7 \mathrm{~kb}$ mRNAs also changes during development. Both bands are of equal intensity at earlier stages, but as of postnatal days 10-15, the intensity of the 6.7 $\mathrm{kb}$ band is stronger. Of the 2 cell lines studied, N2a neuroblastoma cells contain mainly the $7.4,6.7,4.3$, and $2.9 \mathrm{~kb}$ bands and F7 cells those of $6.7,4.3$, and $2.9 \mathrm{~kb}$. In both cell types, a mRNA of $5.2 \mathrm{~kb}$ is very weakly expressed or absent. With their cDNA clones for chicken N-CAM, Murray et al. (1984) detected only 2 mRNAs in embryonic chick brain, which correspond in size to the 7.4 and $6.7 \mathrm{~kb}$ RNAs. No data on N-CAM messages present in the adult chicken are currently available. 
Juxtaposing Northern blot data and immune blot analyses brings out a striking correlation between the presence and relative amounts of $\mathrm{N}-\mathrm{CAM}_{120}$ and the expression of the $5.2 \mathrm{~kb}$ mRNA. During postnatal development, the gradual emergence of the $M_{\mathrm{r}} 120,000$ chain follows a time course similar to that observed for this RNA band. Similarly, the abundance of the $5.2 \mathrm{~kb}$ species can be correlated with the relative amounts of $\mathrm{N}-\mathrm{CAM}_{120}$ present in the adult olfactory bulb and optic tectum, and in the 2 cell lines studied both $\mathrm{N}-\mathrm{CAM}_{120}$ and the $5.2 \mathrm{~kb}$ message are hardly detectable. Seemingly, a similar correlation cannot be made between the other mRNAs and N-CAM ${ }_{180}$ or $\mathrm{N}-\mathrm{CAM}_{140}$. Differences in turnover rates of different N-CAM proteins may account for these discrepancies. Clearly, further work is required to relate the Northern blot data directly to the synthesis of the various size classes of N-CAM.

It is noteworthy that we did not detect $\mathrm{N}-\mathrm{CAM}_{120}$ in the embryonic brain. Previous studies on the polypeptides present in the embryonic form have been fraught with problems of proteolytic degradation occurring during the lengthy neuraminidase digestions necessary to cleave polysialic acid chains (Cunningham et al., 1983; Hirn et al., 1983). Our immune and Northern blot data suggest that the differences between embryonic and adult N-CAM may be greater than anticipated. In contrast to these results, Hansen et al. (1985) detected an $M_{\mathrm{r}} 120,000$ product translated in vitro from embryonic brain polysomes. The reasons for this discrepancy are not clear at present. We agree, however, on the point that the ratios between $\mathrm{N}-\mathrm{CAM}_{140}$ and $\mathrm{N}-\mathrm{CAM} \mathrm{M}_{120}$ change in favor of the latter during postnatal brain development.

The 2 cDNA probes used in the present study differ with respect to the transcripts they recognize. Clone pM3.7 does not hybridize to the 5.2 and $2.9 \mathrm{~kb}$ mRNAs. It follows that these transcripts lack $3^{\prime}$ gene sequences, because pM1.3 contains sequences located $5^{\prime}$ to those contained in pM3.7 (Fig. 1). As described previously (Goridis et al., 1985), pM1.3 detects only mRNAs in N-CAM-expressing tissues and cells, whereas pM3.7 reveals 2 additional bands of smaller size present also in N-CAMnegative cells. The identity of these cross-reacting sequences is still unclear, but the fact that they are not recognized in rat tissues containing all the known N-CAM proteins indicates that the $\sim 1.0$ and $\sim 2.0 \mathrm{~kb}$ bands are not N-CAM messages. The finding that pM3.7 does not hybridize to the $5.2 \mathrm{~kb}$ band supports our contention that this mRNA codes for $\mathrm{N}-\mathrm{CAM}_{120}$, since this N-CAM chain lacks the P61 determinant carried by the translation product of pM3.7.

With our present data we cannot completely rule out the possibility that some of the bands we observe in Northern blots are in vitro degradation products, though the discreteness of the bands and their developmental change would argue against this hypothesis. Neither do we know whether all of the poly(A)+ RNA species detected are functional messages. In vitro translation data suggest that the different size classes of N-CAM polypeptides identified in the rodent brain are synthesized from different mRNAs (Hansen et al., 1985). Of the 5 size classes identified with pM1.3, the $2.9 \mathrm{~kb}$ species may not be large enough to encode N-CAM. This leaves 4 bands with the necessary coding potential, 1 of which may have $3^{\prime}$ - or $5^{\prime}$-untranslated sequences of different length, as demonstrated in other gene systems (Capetanaki et al., 1983). It is still possible that each of the N-CAM proteins of different $M_{\mathrm{r}}$ consists of several closely similar but distinct polypeptides (Chuong and Edelman, 1984; Williams et al., 1985). In this case, 2 of the transcripts we detected could code for such a variant form of N-CAM.

The remarkable decrease in total N-CAM message during postnatal brain development shows that the expression of $\mathrm{N}-\mathrm{CAM}$ is regulated either at the transcriptional level or by mRNA stabilization. However, the approximately 6-fold decrease in total hybridizing poly(A)+ RNA (over 9-fold if the 2.9 $\mathrm{kb}$ band is excluded from the analysis) we observed between birth and postnatal day 40 was considerably higher than the 3fold drop in N-CAM antigen concentration reported by Chuong and Edelman (1984). This implies that posttranslational regulation also occurs. Conceivably, N-CAM has a slower turnover in the adult brain, where it must be transported axonally over considerable distances.

Genomic blot experiments suggest that the mouse genome contains probably only 1 copy of the N-CAM gene (Goridis et al., 1985; Rutishauser and Goridis, 1986). The results of Murray et al. (1984) are also consistent with the presence of a single $\mathrm{N}-\mathrm{CAM}$ gene in the chicken. If this is so, then different transcripts must be derived from the same gene by variations in initiation or termination or by differential splicing. At present, we cannot distinguish between these possibilities. The observation that the more 3 ' located clone pM3.7 does not detect the mRNAs of 5.2 and $2.9 \mathrm{~kb}$ would be most easily explained by assuming that differential termination of transcription is involved, but differential splicing cannot be ruled out. Irrespective of this issue, the important implication of our data is that the mechanism generating the N-CAM mRNAs of different lengths is regulated in a cell-type and developmental-stage specific manner. The biological significance of such a regulation is unknown, but could lead to differential expression of different N-CAM proteins, a view supported by the parallel changes we observed in the prevalence of $\mathrm{N}-\mathrm{CAM}_{120}$ and of the $5.2 \mathrm{~kb}$ mRNA.

Functional differences between the different N-CAM chains have not been demonstrated but are highly likely, since the solubility characteristics of $\mathrm{N}-\mathrm{CAM}_{120}$ are different from those of the other 2 chains (Gennarini et al., 1984b) and since $\mathrm{N}-\mathrm{CAM}_{180}$ has been found to be present preferentially on cellcell contact sites (Pollerberg et al., 1985). Regulation of the total amounts of N-CAM in a given tissue, which, as our data show, is exerted at the nucleic acid level, should be functionally important, since the binding strength of N-CAM interactions is strongly influenced by the concentrations of N-CAM protein (Hoffman and Edelman, 1983).

It will be important in future studies to determine precisely the mcchanism by which the different N-CAM gene transcripts are generated and the polypeptides they code for. Another question raised by our results is whether different N-CAM mRNAs are segregated in different brain cell populations. The changes in the absolute and relative amounts of the mRNAs during development might result from changes in the cellular composition of the tissue or reflect a regulatory event that takes place during differentiation. As more N-CAM cDNA or genomic probes specific for one or the other of the messages will become available, these questions will become accessible to experimentation.

\section{References}

Capetanaki, Y. G., J. Ngai, C. N. Flytzanis, and E. Lazarides (1983) Tissue-specific expression of two mRNA species transcribed from a single vimentin gene. Cell 35: 411-420.

Chuong, C.-M., and G. M. Edelman (1984) Alterations in neural cell adhesion molecules during development of different regions of the nervous system. J. Neurosci. 4: 2354-2368.

Chuong, C.-M., D. A. McClain, P. Streit, and G. M. Edelman (1982) Neural cell adhesion molecules in rodent brains isolated by monoclonal antibodies with cross-species reactivity. Proc. Natl. Acad. Sci. USA 79: 4234-4238.

Cunningham, B. A., B. Hoffman, U. Rutishauser, J. J. Hempcrly, and G. M. Edelman (1983) Molecular topography of the neural cell adhesion molecule N-CAM: Surface orientation and location of sialic acid-rich and binding regions. Proc. Natl. Acad. Sci. USA 80:31163120 .

Edelman, G. M., S. Hoffman, C.-M. Chuong, J.-P. Thiery, R. Brackenbury, W. J. Gallin, M. Grumet, M. E. Greenberg, J. J. Hemperly, C. Cohen, and B. A. Cunningham (1983) Structure and modulation 
of neural cell adhesion molecules in early and late embryogenesis. Cold Spring Harbor Symp. Quant. Biol. 48: 515-526.

Faissner, A., J. Kruse, J. Nieke, and M. Schachner (1984) Expression of neural cell adhesion molecule Ll during development in neurological mutants and in the peripheral nervous system. Dev. Brain Res. 15: 62-82.

Favaloro, J., R. Treisman, and R. Kamen (1980) Transcription maps of polyoma virus-specific RNA: Analysis by two-dimensional nuclease S1 gel mapping. Methods Enzymol. 65: 718-722.

Fcinberg, A. P., and B. Vogclstcin (1984) Addendum. A tcchniquc for radiolabeling DNA restriction endonuclease fragments to high specific activity. Anal. Biochem. 137: 266-267.

Finne, J., and P. H. Mäkelä (1985) Cleavage of the polysialosyl units of brain glycoprotein by a bacteriophage endosialidase. Involvement of a long oligosaccharide segment in molecular interaction of polysialic acid. J. Biol. Chem. 260: 1265-1270.

Finne, J., U. Finne, H. Deagostini-Brazin, and C. Goridis (1983) Occurrence of $\alpha 2-8$ linked polysialosyl units in a neural cell adhesion molecule. Biochem. Biophys. Res. Commun. 112: 482-487.

Fraser, S. E., B. A. Murray. C.-M. Chuong, and G. M. Edelman (1984) Alteration of the retinotectal map in Xenopus by antibodies to neural cell adhesion molecules. Proc. Natl. Acad. Sci. USA 81: 4222-4226.

Gennarini, G., M. Hirn, H. Deagostini-Bazin, and C. Goridis (1984a) Studics on the transmembranc disposition of the neural cell adhesion molecule N-CAM. The use of liposome-inserted radioiodinated NCAM to study its transbilayer orientation. Eur. J. Biochem. 142: $65-73$.

Gennarini, G., G. Rougon, H. Deagostini-Bazin, M. Hirn, and C. Goridis (1984b) Studies on the transmembrane disposition of the neural cell adhesion molecule N-CAM. A monoclonal antibody recognizing a cytoplasmic domain and evidence for the presence of phosphoserine residues. Eur. J. Biochem. 142: 57-64.

Goridis, C., H. Deagostini-Bazin, M. Hirn, M.-R. Hirsch, G. Rougon, R. Sadoul, O. K. Langley, G. Gombos, and J. Finne (1983a) Neural surface antigens during nervous system development. Cold Spring Harbor Symp. Quant. Biol. 48: 527-538.

Goridis, C., G. Rougon, and M. Hirn (1983b) Monoclonal antibodies as probes for neural cell-surface glycoproteins. In Protides of the Biological Fluids, H. Peeters, ed., pp. 529-534, Pergamon, Oxford, U.K.

Goridis, C., M. Hirn, M.-J. Santoni, G. Gennarini, H. Deagostini-Bazin, B. R. Jordan, M. Kiefer, and M. Steinmetz (1985) Isolation of mouse N-CAM related cDNA: Detection and cloning using monoclonal antibodies. EMBO J. 4: 631-635.

Hansen, O. C., O. Nybroe, and E. Bock (1985) Cell-free synthesis of the D2-cell adhesion molecule: Evidence for three primary translation products. J. Neurochem. 44: 712-717.

Hirn, M., M. Pierres, H. Deagostini-Bazin, M. Hirsch, and C. Goridis (1981) Monoclonal antibody against cell surface glycoprotein of neurons. Brain Res. 214: 433-439.

Hirn, M., M. S. Ghandour, H. Deagostini-Bazin, and C. Goridis (1983) Molecular heterogeneity and structural evolution during cerebellar ontogeny detected by monoclonal antibody of the mouse cell surface antigen BSP-2. Brain Res. 265: 87-100.

Hoffman, S., and G. Edelman (1983) Kinetics of homophilic binding by embryonic and adult forms of the neural cell adhesion molecule. Proc. Natl. Acad. Sci. USA 80: 5762-5766.

Ibsen, S., V. Berezin, B. Vøogaard-Pedersen, and E. Bock (1983) Quantification of the D2-glycoprotein in amniotic fluid and serum from pregnancies with fetal neural tube defects. J. Neurochem. 41: 363366.
Keilhauer, G., A. Faissner, and M. Schachner (1985) Differential inhibition of neurone-neurone, neurone-astrocyte and astrocyte-astrocyte adhesion by L1, L2 and N-CAM antibodies. Nature 316: 728730 .

Langley, O. K., G. Gombos, M. Hirn, and C. Goridis (1983) Distribution of the neural antigen BSP-2 in the cerebellum during development. Int. J. Dev. Neurosci. 1: 393-401.

Langley, O. K., M. S. Ghandour, G. Gombos, M. Hirn, and C. Goridis (1982) Monoclonal antibodies as neural cell surface markers. Neurochem. Res. 7: 349-362.

Lehrach, A., D. Diamond, J. M. Wozney, and H. Boedtker (1977) RNA molecular weight determinations by gel electrophoresis under denaturing conditions, a critical reexamination. Biochemistry 16 : 4743-4751.

Lyles, J. M., B. Norrild, and E. Bock (1984) Biosynthesis of the D2 cell adhesion molecule: Pulse-chase studies in cultured rat fetal neuronal cells. J. Cell Biol. 98: 2077-2081.

Maniatis, T., E. F. Fritsch, and J. Sambrock (1982) Molecular Cloning. A Laboratory Manual, Cold Spring Harbor Laboratory, Cold Spring Harbor, NY.

Mura Neto, V., M. Mallatt, H. Chneiwess, J. Prémont, F. Gros, and A. Prochiantz (1986) Two SV40-transformed cell lines from the mouse striatum and mesencephalon present astrocytic character. I. Immunological and pharmacological propertics. Dev. Brain Res. (in press).

Murray, B. A., J. J. Hemperly, W. J. Gallin, J. S. MacGregor, G. M. Edelman, and B. A. Cunningham (1984) Isolation of cDNA clones for the chicken neural cell adhesion molecule N-CAM. Proc. Natl. Acad. Sci. USA 81: 5584-5588.

Noble, M., M. Albrechtsen, C. Møller, J. Lyles, E. Bock, C. Goridis, M. Watanabe, and U. Rutishauser (1985) Glial cells express N-CAM/ D2-CAM-like polypeptides in vitro. Nature 316: 725-728.

Pollerberg, E. G., R. Sadoul, C. Goridis, and M. Schachner (1985) Selective expression of the $180 \mathrm{kD}$ component of the neural cell adhesion molecule N-CAM during development. J. Cell Biol. 101: 19211929.

Rougon, G., H. Deagostini-Bazin, M. Hirn, and C. Goridis (1982) Tissue- and developmental stage-specific forms of a neural cell surface antigen linked to differences in glycosylation of a common polypeptide. EMBO J. $1: 1239-1244$.

Rutishauser, U. (1983) Molecular and biological properties of a neural cell adhesion molecule. Cold Spring Harbor Symp. Quant. Biol. 48: 501-514.

Rutishauser, U., and C. Goridis (1986) NCAM, the molecule and its genetics. Trends Genet. 2: 72-76.

Sadoul, R., M. Hirn, H. Deagostini-Bazin, G. Rougon, and C. Goridis (1983) Adult and embryonic mouse neural cell adhesion molecules have different binding properties. Nature 304: 347-349.

Thanos, S., F. Bonhoeffer, and U. Rutishauser (1984) Fiber-fiber interaction and tectal cues influence the development of the chicken retinotectal projection. Proc. Natl. Acad. Sci. USA 81: 1906-1910.

Thomas, P. S. (1980) Hybridization of denatured RNA and small DNA fragments transferred to nitrocellulose. Proc. Natl. Acad. Sci. USA 77: 5201-5205.

Werner, D., Y. Chemla, and M. Herzberg (1984) Isolation of poly $\left(\mathrm{A}^{+}\right)$ RNA by paper affinity chromatography. Anal. Biochem. 141: 329336.

Williams, R. K., C. Goridis, and R. Akeson (1985) Individual neural cell types express immunologically distinct N-CAM forms. J. Cell Biol. 101: 36-42. 